\title{
ANALISIS MEKANISME TERHADAP PEMBIAYAAN MIKRO DENGAN AKAD MURABAHAH DI PT. BANK SYARIAH MANDIRI BRANCH OFFICE BULELENG
}

\author{
Rini Febriyani Hairi \\ Jurusan Akuntansi Program Diploma III, \\ Universitas Pendidikan Ganesha, Singaraja \\ e-mail : rinifebriyani07@gmail.com
}

\begin{abstract}
Abstrak
PT. Bank Syariah Mandiri Branch Office Buleleng merupakan lembaga keuangan yang berbentuk bank non umum dengan menggunakan prinsip syariah dalam operasionalnya, berdiri di tempat yang strategis di dekat jalan raya yang mudah dijangkau untuk masyarakat, dan memiliki visi dan misi yang dapat memajukannya. Penelitian ini membahas tentang bagaimana pelaksanaan serta analisis terhadap mekanisme pembiayaan mikro dengan akad murabahah di PT. Bank Syariah Mandiri Branch Office Buleleng.

Data yang diperoleh kemudian dianalisis menggunakan metode analisi deskriptif. Penelitian ini menghasilkan pelaksanaan mekanisme pembiayaan mikro dengan akad murabahah PT. Bank Syariah Mandiri Branch Office Buleleng yang terdiri atas pembukaan, pelunasan dan penutupan melibatkan antara nasabah pembiayaan dengan karyawan bagian customer service, account office, dan teller, serta direktur dengan alur yang sederhana dan mudah. Mekanisme tersebut hampir sama dengan mekanisme yang digunakan oleh bank-bank lain, hanya saja terdapat beberapa perbedaan dan modifikasi.
\end{abstract}

Kata Kunci : Mekanisme pembiayaan mikro

\begin{abstract}
PT. Bank Syariah Mandiri Branch Office Buleleng is a financial institution in the form of a non-public bank by using syariah principles in its operations, standing in a strategic place near an easly accessible highway for the community, and have a vision and mission that can advance it. This study discusses how the implementation and analysis terhadap mekanisme pembiayaan mikro with akad murabahah di PT. Bank Syariah Mandiri Branch Office Buleleng. Data obtained then analyzed using descriptive analysis method. This research resulted in the implementation of micro financing mechanism with murabaha scheme of PT. Bank Syariah Mandiri Branch Office Buleleng consisting of opening, settlement and closing involves financing customers with customer service employees, account offices, and tellers, as well as directors with simple and easy grooves. The mechanism is similar to the mechanism used by other banks, but there are only some differences and modifications.
\end{abstract}

Keywords : the mechanism financing mikro

\section{Pendahuluan}

Sejarah perkembangan industri perbankan syariah di Indonesia diawali dari aspirasi masyarakat Indonesia yang mayoritas muslim untuk memiliki sebuah alternatif sistem perbankan yang islami. Perkembangan dunia terus mengalami kemajuan yang sangat signifikan. Ide pendirian Bank Syari'ah di negara-negara Islam tidak terlepas dari kontroversi seputar praktek bunga bank yang dilakukan pada bank-bank konvensional yang beredar di negara-negara Islam sendiri. Pada abad ke 20 timbul kesadaran di kalangan umat Islam untuk melepaskan diri dari imperialisme Barat, membawa dampak yang cukup luas dalam kehidupan sosial politik dan ekonomi ( Materi perbankan syariah, 2015:6).

Dalam dunia ekonomi, negara-negara Islam ingin melepaskan diri dari konsep ekonomi yang berasal dari negara-negara Barat yang tidak sesuai dengan nilai-nilai Islam, antara lain adalah persoalan bunga bank. Oleh karena itu, dipandang perlu adanya bank syari'ah yang bebas dari praktek bunga.

Ide pendirian bank syari'ah di Indonesia tidak terlepas dari adanya wacana yang terus bergulir tentang pendirian bank-bank syari'ah di negara-negara Islam. Ide pendirian 
VOL.6, NO. 2,OKTOBER 2017

p-ISSN : 2337-537X

perbankan syari'ah di Indonesia dapat dilihat dari berbagai keputusan lembaga-lembaga sosial kemasyarakatan maupun pandangan dari para intelektual Islam di Indonesia.

Diawali dengan berdirinya PT. Bank Muamalat Indonesia tahun 1992, yang dalam kurun waktu hanya 7 tahun mampu memiliki lebih dari 45 outlet yang terbesar di Jakarta, Bandung, Balikpapan, Semarang dan Makassar. Perkembangan perbankan syariah pada era reformasi ditandai dengan disetujuinya UU No. 10 Tahun 1998. Dalam undang-undang tersebut diatur dengan rinci landasan hukum serta jenis-jenis usaha yang dapat dioperasikan dan di implementasikan oleh bank syariah. Undang-undang tersebut juga memberikan arahan bagi bank-bank konvensional untuk membuka cabang syariah atau bahkan mengkonversikan diri secara total menjadi bank syariah (Muhammad Syafi'i Antonio, 2001:25).

Secara umum perbankan adalah lembaga yang melaksanakan tiga fungsi utama, yaitu menerima simpanan, meminjamkan uang, dan memberikan jasa pengiriman. Menurut H.M. Sadeq, Bank Islam bukan hanya sebagai tipe yang berbeda dengan bank konvensional tapi keberadaanya sebagai revolusi. Bank Islam tidak sekedar sebagai financial intermediary tapi merevolusi dengan partisipasi nyata dalam bisnis dan mobilisasi dalam pembiayaan. Revolusi pendanaan dapat dibuktikan dengan prinsip sharing profit and losses yang berbeda dengan bank konvensional yang berbasis bunga. Melalui bank kelebihan dana-dana tersebut dapat disalurkan kepada pihak-pihak yang memerlukan dan memberikan manfaat kepada kedua belah pihak.

Menurut jenisnya, bank syariah dibedakan atas Bank Umum Syariah (BUS) dan Bank. Pembiayaan Rakyat Syariah (BPRS). Yang membedakan dari keduanya adalah ada atau tidaknya pemberian jasa dalam lalu lintas pembayaran dalam kegiatan operasionalnya (misalnya :transfer dan kliring), dimana pada Bank Umum Syariah terdapat layanan jasa tersebut sedangkan BPRS tidak. Dalam kehidupan sehari-hari, masyarakat memiliki kebutuhan-kebutuhan yang harus dipenuhi baik kebutuhan, primer, sekunder, maupun tersier. Adakalanya masyarakat tidak memiliki cukup dana untuk memenuhi kehidupan hidupnya. Oleh karenanya, dalam perkembangan perekonomian masyarakat yang semakin meningkat muncul lah jasa pembiayaan yang ditawarkan oleh lembaga keuangan bank maupun lembaga keuangan non bank.

Sebagaimana diketahui, pembiayaan mikro merupakan pembiayaan bank kepada nasabah dengan akad jual beli (murabahah), yang diperuntukkan kepada nasabah yang telah mempunyai usaha mikro dan membutuhkan pengembangan usahanya. UndangUndang No. 21 Tahun 2008 tentang Perbankan Syariah telah merumuskan maksud dari "Akad", bahwa "Akad adalah kesepakatan tertulis antara Bank Syariah atau Unit Usaha Syariah dan pihak lain yang memuat adanya hak dan kewajiban bagi masing-masing pihak sesuai dengan prinsip Syariah". Berdasarkan rumusan tentang akad tersebut, jelaslah bahwa akad memuat sejumlah hak dan kewajiban bagi para pihak, yakni pihak Bank Syariah dan pihak nasabah selaku pemohon akad pembiayaan murabahah. Adapun rumusan masalah yang akan di bahas sesuai dengan latar belakang di atas adalah bagaimana pelaksanaan mekanisme pembiayaan mikro dengan akad murabahah di PT. Bank Syariah Mandiri Branch Office Buleleng dan bagaimana analisis mekanisme pembiayaan mikro dengan akad murabahah di PT. Bank Syariah Mandiri Branch Office Buleleng?

\section{Metodelogi Penelitian}

Rancangan penelitian (Sugioyo, 2003 : 203) adalah pedoman yang berisi langkahlangkah yang akan diikuti oleh peneliti untuk melakukan penelitiannya, rancangan penelitian harus dibuat secara sistematis dan logis sehingga dapat dijadikan pedoman yang betul-betul mudah diikuti.

Rancangan penelitian ini diawali dengan mengumpulkan data-data pembiayaan mikro dan akad murabahah, kemudian data yang terkumpul dan di analisis dengan analisis deskriptif kualitatif.Dari penelitian ini diharapkan bisa diketahui mekanisme pembiayaan mikro dengan akad murabahah di PT. Bank Syariah Mandiri Branch Office Buleleng. 
VOL.6, NO. 2,OKTOBER 2017

p-ISSN : 2337-537X

Metode penelitian merupakan cara kerja untuk dapat memahami obyek yang menjadi sasaran atau tujuan penelitian. Dalam penyusunan tugas akhir ini, penulis menggunakan berbagai metode penelitian. Penelitian ini dilakukan pada PT. Bank Syariah Mandiri Branch Office Buleleng yang beralamatkan di jalan Erlangga, kampung Bugis, Kecamatan Buleleng Kabupaten Buleleng. Subyek dari penelitian ini adalah PT. Bank Syariah Mandiri Branch Office Buleleng, dan Obyek penelitianya adalah Analisis Terhadap Mekanisme Pembiayaan Mikro Dengan Akad Murabahah.

Penelitian ini merupakan penelitian lapangan dengan pendekatan kualitatif. Yang mana pengertian kualitatif adalah penelitian yang bermaksud untuk memahami fenomena tentang apa yang dialami oleh subyek penelitian dengan cara deskripsi dalam bentuk katakata dan bahasa pada suatu konteks khusus yang alamiah dan dengan memanfaatkan berbagai metode alamiah (Lexy J. Moeloeng,2005:6). Yang akan penulis lakukan penelitian di PT. Bank Syariah Mandiri Branch Office Buleleng. Sumber data yang digunakan dalam penelitian ini adalah data primer dan skunder. Data primer adalah data yang dikumpulkan langsung dari lapangan penelitian (Husain Umar, 2002 : 82). Data sekunder adalah data yang diperoleh dari penelitian terdahulu yang dilakukan oleh pihak lain (Sutrisno Hadi, 1993 :11). Data sekunder dalam penelitian ini adalah majalah, artikel, dan buku-buku yang berkaitan dengan penelitian ini.

Dengan tujuan untuk mengetahui mekanisme pembiayaan mikro dengan akad murabahah di PT. Bank Syariah Mandiri Branch Office Buleleng, penulis dalam proses pengumpulan datanya merasa perlu merangkul semua pihak yang berkaitan dengan obyek penelitian ini. Oleh karena itu, metode pengumpulan data yang penulis terapkan antara lain wawancara, observasi, dokumentasi. Wawancara merupakan teknik pengumpulan data dengan cara melakukan tanyajawab. Metode wawancara ini berguna bagi penulis dalam menggali informasi secara langsung kepada informan (pemberi informasi) baik kepada direktur, karyawan maupun bagian pengelola divisi sosial di PT. Bank Syariah Mandiri Branch Office Buleleng guna memperoleh data yang diharapkan. Observasi adalah sebuah kegiatan yang terencana dan terfokus untuk melihat dan mencatat serangkaian perilaku ataupun jalannya sebuah system yang memiliki tujuan tertentu, serta mengungkap apa yang ada dibalik munculnya perilaku dan landasan suatu system tersebut. Observasi yang dilakukan adalah dengan cara mengamati secara langsung mengenai obyek yang diteliti. Dokumentasi adalah metode yang dilakukan dengan cara mencari data tentang hal-hal yang berkaitan dengan pembahasan dalam penelitian.

Analis adalah proses menghubungkan, memisahkan dan mengelompokkan antara fakta yang satu dengan fakta yang lain sehingga dapat ditarik kesimpulan sebagai akhir pembahasan. Metode analis yang digunakan penulis tugas akhir ini adalah metode deskriptif. Deskriptif adalah metode dalam meneliti status kelompok manusia, suatu objek, suatu kondisi, suatu system pemikiran ataupun suatu kelas pemikiran pada masa sekarang. Tujuan dari deskriptif ini adalah untuk membuat deskriptif gambaran atau lukisan secara sistematis, faktual dan akurat mengenai fakta-fakta. sifat-sifat serta hubungan antar fenomena yang diselidiki. Berdasarkan metode ini penulis ingin menggambarkan bagaimana mekanisme pembiayaan mikro dengan akad murabahah di PT. Bank Syariah Mandiri Branch Office Buleleng.

\section{Hasil dan Pembahasan}

Pembiayaan mikro PT. Bank Syariah Mandiri adalah pembiayaan bank kepada nasabah perorangan atau badan usaha yang bergerak di bidang UMKM untuk membiayai kebutuhan usahanya melalui pembiayaan modal kerja atau pembiayaan investasi dengan maksimal limit pembiayaan Rp 15.000.000 sampai dengan Rp. 200.000.000. Persyaratan yang mudah, proses pembiayaan cepat dan angsuran ringan serta tetap hingga jatuh tempo adalah nilai plus terhadap pembiayaan mikro ini. Dengan keunggulan tersebut maka diharapkan dengan fasilitas yang diberikan mikro. Masyarakat kecil dan pelaku UMKM dapat tetap menjalankan roda perekonomiannya secara maksimal. 
Akad yang digunakan pada produk pembiayaan mikro adalah akad murabahah. Implikasi dari pengguna akad murabahah mengharuskan adanya pen jual, pembeli dan barang yang dijual. Sebagaimana diketahui dalam skim murabahah fungsi bank adalah sebagai penjual barang untuk kepentingan nasabah, dengan cara membeli barang yang diperlukaan nasabah dan kemudian menjualnya kembali kepada nasabah dengan harga jual yang setara dengan harga beli ditambah keuntungan bank dan bank harus memberitahukan secara jujur harga pokok barang berikut biaya yang diperlukan dan menyampaikan semua hal yang berkaitan dengan pembelian barang kepada nasabah.

Pada aplikasinya bank syariah menggunakan media 'akad wakalah'dengan memberikan kuasa terhadap nasabah untuk membeli barang tersebut. Dengan adanya akad wakalah tersebut bank sepenuhnya menyerahkan dana tersebut kepada nasabah untuk membeli barang-barang yang dibutuhkan oleh nasabah. Selain itu dalam aplikasinya akad jual beli murabahah dilakukan sebelum barang secara prinsip menjadi milik bank. Hal ini tentunya tidak sesuai dengan ketentuan Fatwa MUI No.04/DSN-MUI/IV/2000 tanggal 1 April 2000 yang menetapkan bahwa jika bank hendak mewakilkan kepada nasabah untuk membeli barang dari pihak ketiga, maka akad jual beli murabahah harus dilakukan setelah barang secara prinsip menjadi milik bank. Masalah ini tentunya harus betul-betul diperhatikan oleh bank-bank syariah yang ada karena masalah ini bisa berpotensi menurunkan citra bank syariah itu sendiri. berikut:

Adapun perbedaan antara murabahah dan kredit konvensional adalah sebagai

1. Prinsip dasar yang dipakai murabahah adalah akad jual beli sedangkan prinsip dasar yang dipakai kredit konvensional adalah pinjam meminjam.

2. Dalam praktek pembiayaan murabahah,hubungan antara bank syariah dan nasabahnya adalah penjual dan pembeli, sedangkan pada kredit konvesional, hubungan antara bank konvensional dan nasabahnya adalah hubungan kreditur dan debitur.

3. Dalam murabahah hanya menghendaki satu harga dan tidak tergantung dengan jangka waktu pembayaran, sedangkan kredit konvensional mengharuskan adanya perbedaan pembayaran sesuai dengan jangka waktu yang telah ditentukan. Semakin lama waktu pembayaran semakin besar jumlah tanggungan yang harus dibayar.

4. Keuntungan dalam praktek murabahah berbentuk margin penjualan yang didalamnya sudah termasuk harga jual, sedangkan keuntungan pada kredit konvensional didasarkan pada tingkat satu suku bunga. Nasabah yang mendaptkan kredit dari bank konvensional dibebani kewajiban membayar cicilan beserta bunga pinjaman sekaligus.

Secara garis besar para nasabah dari produk pembiayaan mikro memandang bahwa tidak ada masalah dengan aplikasi dari konsep murabahah pada produk pembiayaan mikro. Menurut mereka produk ini sudah cukup baik dan sangat menolong bagi pengusaha yang memilki usaha mikro dan kecil yang membutuhkan fasilitas pembiayaan. Dari pengalaman nasabah pembiayaan mikro mereka sudah cukup puas dengan pelayanan dan fasilitas dari produk pembiayaan mikro.

Secara konsep produk ini sudah sesuai dengan ketentuan-ketentuan yang ada dalam akad murabahah. Dalam aplikasinya memang belum semua ketentuan-ketentuan yang ada sudah dijalankan sebagaimana mestinya. Misalnya posisi bank sebagai penjual terkesan hilang karena memang bank hanya mewakilkan pada nasabah untuk membeli barangbarang yang dibutuhkan sehingga seolah-olah barang yang dibeli nasabah langsung menjadi milik nasabah, padahal seharusnya barang tersebut menjadi milik bank terlebih dahulu. Hal ini tentunya akan membuat aplikasi pada produk ini terkesan sama dengan produk kredit yang ada pada bank konvensional. Hal ini merupakan salah satu cerminan dimana saat ini belum murni syariahnya bank syariah yang ada di Indonesia.

Kegiatan monitoring selanjutnya adalah melalui beberapa analisis, selain dengan melakukan pengawasan, PT. Bank Syariah Mandiri Branch Office Buleleng juga melakukan 
monitoring melalui analisis penelitian pembiayaan. Adapun analisis yang sering digunakan antara lain $5 \mathrm{C}+1 \mathrm{~S}, \mathrm{Ke}-5 \mathrm{C}$ tersebut antara lain:

\section{Character}

Character merupakan suatu penilaian atau analisis terhadap watak atau sifat nasabah. Dalam hal ini, watak dan sifat dari anggota akan menentukan apakah anggota tersebut layak untuk diberikan pembiayaan atau tidak. Untuk menentukan watak atau sifat dari calon anggota pembiayaan, PT. Bank Syariah Mandiri Branch Office Buleleng menilainya dari segi seberapa cepat dana yang dibutuhkan calon anggota akan cair, jika dengan pembiayaan yang diajukan cukup besar dan ingin terburu-buru, maka hal ini patut dipertanyakan. Jika terhadap pengajuan pembiayaan yang seperti ini, petugas lapangan atau marketing akan meneliti lebih lanjut calon anggota pembiayaan. Mulai dari melihat jaminan yang diberikan, mengamati usaha calon anggota, mencari informasi dari pihak ketiga tentang bagaimana watak atau sifat calon nasabah tewrsebut.

\section{Capacity}

Capacity merupakan penilaian atau analisis mengenai seberapa besar kemampuan calon anggota dalam membayar kewajibannya terhadap BSM. Penilaian capacity ini bisa dilihat dari bukti sruk pembayaran listrik, PDAM, atan bisa dilihat dari gaya hidup calon anggota. Jika pengeluaran lebih besar daripada pemasukan atau penghasilan yang didapat dari calon anggota, maka pemberian pembiayaan akan lebih dipertimbangkan lagi. Tetapi jika penghasilan yang diterima lebih besar daripada pengeluarannya, dengan mempertimbangkan watak dari calon anggota, maka pembiayaan bisa dilaksanakan sesuai dengan prosedur yang ada.

\section{Capital}

Capital merupakan suatu sumber dari penghasilan calon anggota. Sebelum pemberian pembiayaan, pihak BSM juga akan melihat seberapa besar dan seberapa banyak sumber penghasilan yang diterima calon nasabah. Capital ini bisa dilihat dari formulir pengajuan pembiayaan pada kolom perhitungan penghasilan tiap bulan.

\section{Collateral}

Collateral merupakan jaminan dari pembiayaan. Dalam hal jaminan, PT. Bank Syariah Mandiri Branch Office Buleleng memiliki dua kategori jaminan yang bisa untuk dijadikan, antara lain :

a) BPKB Kendaraan

Kriteria jaminan kendaraan ini, dilihat dari surat-surat keterangan dari kendaraan tersebut mulai dari nomor polisi, merek kendaraan, kepemilikan kendaraan, tahun kendaraan dan surat-surat lain yang menunjang informasi mengenai kendaraan yang akan dijadikan jaminan. Keadaan fisik kendaraan tidak menutup kemungkinan untuk menjadi bahan pertimbangan pemberian pembiayaan.

b) Sertifikat

Dalam hal sertifikat, sertifikat ini bisa digolongkan kedalam dua bagian yakni sertifikat rumah dan sertifikat tanah. Jika yang dijadikan jaminan merupakan sertifikat rumah, maka pihak PT. Bank Syariah Mandiri Branch Office Buleleng akan mensurvei rumah tersebut. Tetapi jika yang dijadikan jaminan merupakan sertifikat tanah, maka pihak PT. Bank Syariah Mandiri Branch Office Buleleng akan mensurvei tanah dan juga rumah yang ditinggali calon nasabah.

\section{Condition}

Condition of econmy merupakan suatu kondisi ekonomi calon nasabah. Dalam hal ini, PT. Bank Syariah Mandiri Branch Office Buleleng akan melihat bagaimana keadaan ekonomi calon anggota berdasarkan seberapa besar usaha atau sumber penghasilan calon 
anggota bisa menutupi kebutuhan dan kewajibannya. Penilaian akhir bisa ditentukan setelah mempertimbangkan Keempat $\mathrm{C}$ diatas.

Sedangkan $1 \mathrm{~S}$ yang dimaksud adalah Syariah, sesuai dengan namanya, PT. Bank Syariah Mandiri Branch Office Buleleng memilki prinsip syar'i yang cukup baik. Pembiayaan murabahah atau pembiayaan yang disalurkan harus sesuai kebutuhan calon anggota dalam arti bukan merupakan kebutuhan konsumtif maupun kebutuhan yang dilarang oleh hukum Islam. Terdapat beberapa usaha yang tidak dapat dibiayai melalui akad murabahah atau jual beli ini, antara lain: Perusahaan rokok, perusahaan atau usaha minuman keras, praktek jual beli ijon, pembelian kendaraan atau barang-barang mewah.

\section{Simpulan dan Saran}

PT. Bank Syariah Mandiri Branch Office Buleleng merupakan lembaga keuangan yang berbentuk bank non umum dengan menggunakan prinsip syariah dalam operasionalnya, berdiri di tempat yang strategis di dekat jalan raya yang mudah dijangkau untuk masyarakat, dan memiliki visi dan misi yang dapat memajukannya. Penelitian ini membahas tentang bagaimana pelaksanaan serta analisis terhadap mekanisme pembiayaan mikro dengan akad murabahah di PT. Bank Syariah Mandiri Branch Office Buleleng.

Data yang diperoleh kemudian dianalisis menggunakan metode analisi deskriptif. Penelitian ini menghasilkan pelaksanaan mekanisme pembiayaan mikro dengan akad murabahah PT. Bank Syariah Mandiri Branch Office Buleleng yang terdiri atas pembukaan, pelunasan dan penutupan melibatkan antara nasabah pembiayaan dengan karyawan bagian customer service, account office, dan teller, serta direktur dengan alur yang sederhana dan mudah. Mekanisme tersebut hampir sama dengan mekanisme yang digunakan oleh bank-bank lain, hanya saja terdapat beberapa perbedaan dan modifikasi. 


\section{DAFTAR PUSTAKA}

Ascarya, Akad dan Produk Bank Syariah, Jakarta : PT Raja Grafindo Persada, 2007

Depertemen Agama, RI. AI-Qur'an dan Terjemah, Jakarta : PT Insan Media Pustaka, 2013

Dessy, "Pengertian dan Kriteria UMKM", Artikel ini diakses pada 20 April 2015 dari Fakultas Ekonomi dan Bisnis Islam Universitas Islam Negeri Walisongo Semarang,

http://chichimoed.blogspot.com/2009/03/pengertian-dan-kriteria-ukm.html

http://materiperbankansyariah.blogspot.co.id/2015/06/makalah-perkembangan-bank-syariahdi.html

http://repository.uinjkt.ac.id/dspace/bitsteam/123456789/2916/1/TRYPRASETO-FSH.pdf diakses 20 April 2015

Lutkhiyah, "Aplikasi Pembiayaan Akad Murabahah di KJKS BMT Al-Hikmah Ungaran", Tugas Akhir

Muhammad Syafi'i Antonio, Bank Syariah: Dari Teori Ke Praktik, Jakarta: Gema Insani, 2001, cet ke 1

Tulus T. H Tambunan, UMKM di Indonesia, Jakarta: Ghalia Indonesia, 2009

Undang-undang Nomor 21 Tahun 2008 Tentang Perbankan Syari'ah Pasal 1 